\author{
Professor Florin GEORGESCU, PhD \\ The Bucharest University of Economic Studies \\ Gheorghe GHERGHINA, PhD \\ Ana-Maria CAZACU, PhD (Corresponding author) \\ E-mail: ana02mary@yahoo.com
}

\title{
THE CORRELATION BETWEEN ROMANIAN FINANCING PATTERN OF FIRMS AND FIXED CAPITAL FORMATION IN THE REAL SECTOR
}

\begin{abstract}
This paper focuses mainly on the analysis of the firms' financing structure, the rationale being that it is a relevant element for the growth potential of the real sector and, implicitly, the national economy. Data at European level illustrate that insufficient own sources entail a modest level and quality of investment, thereby confining the contribution of capital to economic growth. Information at microeconomic level pinpoints that high indebtedness, for a significant part of domestic companies, when the economic crisis broke out, caused the investment rate to decline more abruptly. Specifically, it appears that overlyindebted companies carry out a marked pro-cyclical economic activity, which is, however, vulnerable to significant corrections required by adverse economic events. In general, heavily-indebted companies continue to report weaker financial indicators and lower productivity than the firms for which own sources of financing are prevalent in the balance sheet. These developments, combined with the large share of the hidden economy, weigh on competitiveness and the sustainable growth prospects of Romania's economy.
\end{abstract}

Keywords: capitalisation, investment, indebtedness, hidden economy, structural reforms.

\section{JEL Classification: D22, D24, E22, E26, E32}

1. Firms' financing structure and the level of production

In the literature on production behaviour and the financial theory, respectively, financial and output decisions are generally dealt with separately. From among the best-known theories on the firms' financing structure, worth mentioning is the one developed by Modigliani and Miller (1958), according to which, in the absence of taxation and in a perfect market, the market value of a company is not influenced by the manner in which the firm is financed. Nevertheless, it is obvious that there are important linkages between production behaviour and financial behaviour. For example, Brander and Lewis (1986) show that shareholders' limited liability may 
commit a leveraged firm to a more aggressive output stance, to taking riskier decisions. Specifically, in light of the limited liability principle, as indebtedness rises, companies will adopt higher-yield production strategies in times of a boom, entailing heavier losses in a bust. Leach et al. (2004), patterning on Brander and Lewis (1986), show that although more heavily-indebted firms tend to produce more, considering that production is confined to the extant capacities, the increase in debt beyond a certain threshold may no longer lead to an expansion of production. A similar conclusion is drawn by Gebauer et al. (2017) who investigate the link between corporate debt and investment for a group of five peripheral euro area countries in 2005 -2014. The paper looks at a non-linear relationship between corporate debt and investment activity, the authors identifying a threshold beyond which leverage has a negative and significant impact on investment. Moreover, the outcome suggests that even moderate debt levels may depress investment for smaller firms or when profitability is low. Duval et al. (2017) show that firms which, at the onset of the 2008 economic and financial crisis, experienced a more fragile financial position (higher indebtedness or larger debt-to-equity ratios in the near run) saw a significantly greater fall in total productivity in the post-crisis period, also on the back of a substantial drop in investment, impacting intangible capital goods in particular. A similar conclusion is reached by Kalemli-Özcan et al. (2018) who, based on company level data from eight European countries, specify that the decline in those countries' investment in the post-crisis period owed to high indebtedness and an increase in debt service. The authors argue that the stateof-affairs in the European countries - where net investment of the corporate sector (as a percentage of GDP) failed to resume the 2008 level, as opposed to the US A where the recovery was much faster (2014 saw a return to the 2008 level) - is attributed to the European firms' debt overhang in the run-up to the crisis.

In turn, Keuning (1999) considers that the liabilities side of a firm's balance sheet should be seen as a separate input in the production process, unlike the current practice in which the capital stock is viewed as being on a par with fixed assets. The study takes the economic cost of capital as a point of departure, showing that cost is what matters in the real world, both to the users of capital services and to the suppliers, as it represents their remuneration. In other words, capital does not refer solely to fixed assets, but rather to the financing sources. Against this backdrop, this paper puts forward for consideration a shift in the emphasis of the analysis from the assets side to the liabilities side. We believe that this redesign of the production model could shed new light on the productivity growth differences among firms, industries or countries and, implicitly, on the drivers of economic growth. Therefore, Keuning (2009)points out that acknowledging financial capital as a factor of production counts among the needs of users of statistics on national accounts for 2020, while Diewert (2014) argues that the current system of national accounts does not provide a satisfactory framework for the integration of financial transactions into production accounts. 
The Correlation between Romanian Financing Pattern of Firms and Fixed Capital Formation in the Real Sector

\section{Economy-wide capital stock and the current state of firms' financing in Romania}

Fixed capital stock in Romania is generally estimated by using the perpetual inventory method (PIM), this method consisting of accumulating capital formation and deducting the value of assets that reached the end of their useful life ${ }^{1}$. Based on these estimates, it notes that, compared to other countries, both advanced economies and former socialist countries in Central and Eastern Europe, Romania has a low capital-output ratio. In 2017, the share of capital in Romania's GDP stood at 2, lagging behind: (i) the EU average (2.9), (ii) advanced economies such as Sweden, Austria and Spain (3.5), France (3.1), Finland (3) and (iii) peers in the region: Czechia (2.8), Croatia (2.5), Bulgaria (2.4), etc. Similarly, in regard to labour, Romania posted the lowest level of fixed assets per employee (EUR 43,000 per) compared to more than EUR 300,000 per employee in Norway (EUR 361,000), Switzerland (EUR 343,000), Sweden (EUR 329,000), or Czechia (EUR 110,000), Slovenia (EUR 84,000), Croatia (EUR 75,000), etc..In general, a positive relationship can be detected between a country's level of development and its capital stock, developed countries (Sweden, Austria, France, etc.) reporting a high capital-output ratio, as well as an elevated level of fixed assets per worker.

Not only does Romania post lower levels of indicators on fixed capital endowment than most developed countries in Europe, but also when looking at the firms' financing pattern, the model is different from the other countries under review. Even though fixed capital formation is a complex process, influenced by a broad range of factors (efficiency of the business environment, quality of institutions, level of confidence of economic agents ${ }^{2}$, training and entrepreneurial culture, etc.), we believe that firms' financing structure is highly relevant to the companies' investment behaviour, as we will show below. In this respect, Romania stands out as the country with the most elevated level of indebtedness. Moreover, it notes that the debt-to-equity ratio of firms in Romania increased significantly between 1994 and 2016, from only 26\% in 1994 to 206\% in 2016, having peaked at $244 \%$ in 2012 . In 2017 , firms' debt-to-equity ratio fell slightly to $191 \%$, driven by a $9 \%$ rise (up EUR 8.5 billion) in the corporate capital stock, which offset the increase in debt by $0.8 \%$ (up EUR 1.6 billion). The upswing in equity masks different developments between: (i) the group of companies that experienced a significant increase in own sources of financing (up EUR 16.9 billion) comprising 269,000 firms (41\% of total), where the capital stock increase is highly concentrated, with top-10 companies rated by the increase in equity totalling a gain

\footnotetext{
${ }^{1}$ For the depreciation rate, as appropriate, various authors single out a constant value, i.e. $5 \%$ annually (Altăr et al., 2010), and, in general, the initial time of capital stock estimation is set for 1995, when the value of physical capital is set to be twice that of the GDP.

${ }^{2}$ NBR (2019) shows that an increase in economy-wide uncertainty puts a drag on investment, with a more volatile economic environment affecting especially small- and medium-sized enterprises.
} 
of EUR 2.1 billion (12\% of the total increase) and top-100 companies boosting their own funds by EUR 5.1 billion (30\% of total) and (ii) the group of companies for which the capital stock contracted substantially (down EUR 11.7 billion), which is also very large, i.e. 222,000 units (34\% of total).The advance in capital also occurred amid the pick-up in start-ups, these companies ${ }^{3}$ accounting for approximately $31 \%$ (EUR 2.6 billion) of the capital stock increase in 2017 . The breakdown of start-ups in the local economy shows that this phenomenon was recorded, conditional on company size, chiefly by micro-enterprises (98\% of the number of start-ups) and, by sector, particularly in services (in general low-skilled) and trade (47\% and $26 \%$ respectively of total). Taking into account these aspects, the good performance of the debt-to-equity ratio in 2017 should be interpreted with caution.

It should also be noted that the quite large share of capital (80\%) in the balance sheet total, as seen in 1994, was patterned on the own funds' structure in the socialist period, characterised by an extensively developed industrial sector, a fairly large volume of fixed assets (whose counterpart on the liabilities side was the "fixed assets fund") and a low amount of the fund of circulating assets. Working capital was supplemented, prior to 1989 , by bank loans granted under the plan, which made it possible to exert "control through the leu" over socialist enterprises. However, in the context of strains within the plan, the volume of loans could not secure enough financial sources to comply with the expected length of the production cycle, so that more than often a significant immobilisation of circulating assets was recorded. According to the socialist accounting system, fixed and current assets had as counterparts, on the liabilities side, a separate reflection of the funding of fixed assets and current assets by means of fixed assets fund and the fund of circulating assets. The new accounting methodology introduced in 1994 unified the fixed assets fund and the fund of circulating assets under "capital", giving the impression of very good capitalisation of former socialist state-owned companies in relation to their debt. But it was only a façade, because the core of the problem remained in place, namely too little working capital as compared to the amount of fixed capital, calling for restructuring and capitalisation of firms, together with their privatisation based on a coherent and effective national strategy in terms of preserving the country's productive potential in competitive sectors. Starting in 1997, the authorities opted for the privatisation of state-owned companies with no price limit, shifting the burden of capitalisation onto the new owner, who was to decide on the company's future activity. This brought about two phenomena: (i) the activity of large socialist enterprises (the so-called 'behemoths') that were heavily endowed with fixed capital and under-funded with working capital was phased out, and (ii) the new privately-owned companies made market entry - under the then legislation, they enjoyed very soft capital requirements and were allowed a loose financial discipline. Those developments

\footnotetext{
${ }^{3}$ The firms that had submitted financial statements to the Ministry of Public Finance in
} 2017 were taken into account, as they were not included in the 2016 database. 
The Correlation between Romanian Financing Pattern of Firms and Fixed Capital Formation in the Real Sector

echoed in the current level of the Romanian corporate sector capitalisation, one of the lowest across the EU. One may conclude that the present-day market economy in Romania is based, paradoxically, mainly on debt, not capital.

We consider that such a state of affairs, proving a high level of debt accrued by domestic companies, stifles firms' investment potential and thus the potential and effective economic growth. With this in view, a recent analysis prepared by the National Bank of Romania (2019) on the reasons behind Romania's poor performance in terms of investment, both in relation to the 2008 peak and compared to other emerging economies in the region (Czech, Poland, Hungary), shows that one of the key determinants for the modest development of gross fixed capital formation in the economy is the firms' indebtedness. Furthermore, the recovery in demand since 2014 as well as the improved confidence in the economy failed to prompt a significant rebound in capital accumulation. NBR econometric results show that debt overhang weighs heavily on investment decisions - a onepercentage-point increase in leverage (calculated as the ratio of total debt to total assets) reduces the likelihood of a firm's investment by 0.7-0.8 percentage points. By taking a closer look at capitalisation at firm level, we show that the aggregate indebtedness indicator of $191 \%$ in 2017 is characterised by poor representativeness across Romania's corporate sector. In fact, there are two distinct categories of companies, as follows: (1) the category of firms reporting a prudent financial standing, i.e. a sub-par debt-to-equity ratio, with 34\% (221,100 units) of companies in Romania (the average of the debt-to-equity ratio for this category of firms stands at a mere 30\%); and (2) at the opposite pole, the much larger category encompasses overly-indebted firms, namely: companies with negative equity (debt overtook total assets), accounting for 39\% (254,700 units) of total; and firms recording a level of indebtedness higher than the prudential threshold of 1 (but with positive equity), making up $24 \%$ of total (157,700 units) - average indebtedness for this category of companies is quite high at $293 \%$.

Moreover, companies in Romania finance their fixed assets through their own sources (equity) to a lesser extent than the vast majority of other European countries. The ratio of shareholders' equity to fixed assets in Romania was only $64 \%$ in 2017, which is markedly lower than in other countries where the companies' equity exceeds the total of fixed assets: the ratio of the two indicators is upwards of $200 \%$ in France (286\%), the Netherlands (258\%), Sweden (224\%), Denmark (206\%), Belgium (203\%), and in Luxembourg it is particularly elevated $(560 \%)$. The former socialist countries in the region also paint a more prudent picture: Poland (105\%), Hungary (97\%), Lithuania (80\%). An exception among the developed countries is Austria, where the ratio of shareholders' equity to net fixed assets is only $57 \%$. Such a situation, where firms are highly reliant on their creditors and autonomy in funding fixed capital is thus extremely feeble, raises concerns over the stability, quality and complexity of the capital stock across the corporate sector. Thus, while the own sources of companies in Romania cover only $64 \%$ of fixed assets, the firms need to get into debt not only to expand, but also to 
preserve the level of the existing investment. Assuming adverse developments, which could hamper the financial willingness of creditors (business partners, banks, etc.), heavily-indebted firms in particular may find it difficult to secure resources for their day-to-day activity and investment (see Section 3 below). Such a context leads to a slowdown in the growth rate of capital stock, which in turn puts a damper on the economy's growth potential. Moreover, companies in Romania have, in recent years, also recorded a worsening of their short-term financial autonomy, i.e. the coverage of short-term debt through current assets declined to $98.5 \%$ in 2017, compared to above-par values of $103 \%$ in 2006 and $100 \%$ in 2007.

It should be pointed out that the countries reporting an adequate relationship between shareholders' equity and fixed assets of firms generally post a significantly higher level of investment relative to the number of employees. Specifically, in 2016, industrial firms doing business in the countries registering an above-par ratio of own sources to fixed capital saw, on average, investment worth EUR 10,000 per employee, whereas in the countries where the shareholders' equity coverage of fixed assets is below one, investment amounts to only EUR 6,600 per worker. In Romania, industry-wide enterprises invest only EUR 4,600 per employee, i.e. half the European average of EUR 8,600 per employee. Other relevant papers (Guda, 2019) show that new long-term investment by local firms reflecting asset renewal was significantly slower than depreciation (the loss of market value over time). The author shows that, at company level, new investment made in the course of 2017 hit a ten-year low of lei 8.1 billion, almost ten times less than a year earlier. As for investment in Romania, the following key findings by the EIB $(2018)^{4}$ are also worth mentioning:

- In 2018, only 68\% of the companies in Romania reported they had realised investment ${ }^{5}$, sharply below (19 percentage points) the EU-wide average of $87 \%$ (Romania is placed in the "low investment expanding" quadrant of the investment cycle).Moreover, the share of investment in intangible assets ( $R \& D$, databases, organisational capital, software, and so on) is significantly lower than the EU-wide average: $25 \%$ versus $36 \%$.

- Investment is attributed up to $40 \%$ to the need for replacement of the existing fixed assets, 33\% of investment levels in 2018 were aimed at expanding capacity for existing products or services, while only $13 \%$ of investment were made for developing new products, processes or services.

- The quality of firms' fixed assets remained weak, given that the average share of equipment seen by firms as "state-of-the-art" equals only $28 \%$ in Romania against $44 \%$ in the EU (a gap of 16 percentage points). Moreover, they assessed their machinery and equipment to have worsened compared to the 2017 survey, when the share of state-of-the-art equipment was

\footnotetext{
${ }^{4}$ See the EIB Investment Survey (2018).

${ }^{5}$ A firm is perceived to have realised investment if it spent more than EUR 500/employee for investment activity with the aim of preserving or expanding its future earnings.
} 
The Correlation between Romanian Financing Pattern of Firms and Fixed Capital Formation in the Real Sector

perceived at 35\%.Against this background, total factor productivity of local firms is significantly lower than the EU-wide average, as almost $79 \%$ of the companies in Romania are in the lowest quintile of productivity.

- Nonetheless, $77 \%$ of the enterprises in Romania deem they had invested enough over the last 3 years, which may be an explanation for the modest performance of gross fixed capital formation in the recent past.

Not only do the meagre sources of financing of firms in Romania in relation to the fixed capital stock entail a low volume of investment, but when companies have the possibility to invest, the money is only partly channelled into complex, modern/automated production means. Specifically, it notes that the complexity of the production process is negatively affected by the inadequate ratio of shareholders' equity to fixed assets, which is commonplace in other European countries as well. On the one hand, with few exceptions, most of the countries where the firms' own sources are too low compared to fixed assets report a paltry percentage (3\% against the EU average of 7\%) of companies using robots in the industrial sector or for the provision of services: Hungary (97\% coverage of fixed capital from own sources), Greece (81\%), Lithuania (80\%) and Romania (64\%). On the other hand, among the countries with the highest percentage of companies using robots in the production process are those recording a very good ratio of shareholders' equity to fixed assets. Specifically, in Denmark, about $10 \%$ of firms use robots (the second highest level in the EU, after Spain on 11\%) and the ratio of shareholders' equity to fixed assets amounts to $206 \%$. In Finland, where also $10 \%$ of companies use robots, firms' equity overtakes fixed assets (at a ratio of $136 \%$ ). The following countries rated by the share of firms using robots are Italy, with $9 \%$ of such firms (for which the ratio of equity to fixed assets is almost at par, i.e. 96\%), France, the Netherlands and Portugal, where $8 \%$ of companies use robots, given an above-par ratio of firms' equity to fixed capital $(286 \%, 258 \%$ and $112 \%$ respectively). These developments show undoubtedly that the volume of firms' own funds influences both the level and the quality of investment.

In this vein, it is worth noting that the reckless financing of fixed assets of firms in Romania is reflected not only by their meagre own sources, but also by the fact that companies recorded an increase mainly in short-term indebtedness over the past few years. Specifically, data taken from the Financial Accounts show that firms' debt in the form of trade credit grew markedly, from 2013 to 2017, by $34.5 \%$ (up lei 179.2 billion, from lei 519.9 billion to lei 699.1 billion) and, as part of this type of financing, the item "other accounts payable" (including mainly unpaid debt under contractual terms) increased at the fastest pace, by 58\% (up lei 144.8 billion, from lei 249.6 billion to lei 394.4 billion). By contrast, bank loans granted to firms dropped slightly (by $0.8 \%$ or lei 2.5 billion respectively, from lei 308.6 billion to lei 306.1 billion), owing to the decline in long-term loans (by $1.1 \%$ or lei 2.4 billion respectively, from lei 210 billion to lei 207.6 billion), while shortterm loans remained virtually flat in the reviewed period (lei 98.5 billion). This development strengthens the conclusion that the faulty financing pattern of firms in 
Romania dampens investment quality, given that local companies end up funding their fixed assets by resorting to part of current liabilities, which does not provide a safety margin for long-run financing (Georgescu, 2018).

Other factors that may explain the slow dynamics of Romania's fixed capital stock and its poor quality compared to the country's development needs are, aside from the weak quality of investment by the corporate sector, the lower use of production capacities compared to other European countries. As such, it is noteworthy that Romania has one of the lowest levels of capacity utilisation in industry in relation to other EU Member States, only 75\% at end-2018, i.e. 8 percentage points below the EU-wide average of $83 \%$ and markedly lower than the best-performing countries, including ex-communist countries in the region: Austria (89\%), Sweden and Slovakia (88\%), Germany and Hungary (87\%), etc. Low capacity utilisation across firms in Romania is of particular concern, especially since over latter years, despite an expansion in economic activity, this indicator has steadily worsened (from $80 \%$ in 2014 to $75 \%$ in 2018) and the gap relative to the EU-wide average has widened (from only 1 percentage point in 2014 to 8 percentage points in 2018).The firms' low financial autonomy, the weak quality of investment and the relatively low capacity utilisation in Romania puts a drag on the strength of capital factor to boost economic growth. In fact, the analysis of the correlation between the ratio of shareholders' equity to fixed assets and contributed capital to potential GDP growth shows that: (i) in the countries where own financing sources exceed fixed assets - testifying to firms' capability to support additional investment from shareholders' equity -, the direct contribution of capital to potential growth stands, on average, at $40 \%$, while (ii) in the countries where the ratio of shareholders' equity to fixed assets is below par, the contribution of capital to potential GDP growth amounts, on average, to merely $23 \%$.

\section{Analysis of the correlation between the firms' economic performance, investment rate and indebtedness}

Building on findings in literature that proved the negative effect of elevated indebtedness on firms' investment, as well as on evidence confirming this assumption in Romania, we conducted an empirical exercise aimed at analysing the impact of the recent financial crisis on local companies' performance and the investment rate, based on their financing structure when the crisis broke out. Specifically, companies were split into two groups, according to their level of indebtedness, as follows: (i) overly-indebted firms (with an above-par debt-toequity ratio or negative equity) and (ii) companies with a more prudent financing structure, whose shareholders' equity is prevalent in the balance sheet (below-par debt-to-equity ratio). We analysed firms' state in the pre-crisis period, i.e. from 2004 to 2008, placing them in either of the two groups based on the debt-to-equity ratio during at least 3 years of that period. We left aside the firms that entered and exited the market very quickly and could distort the analysis (with reports submitted for less than 3 years) and ensured that the financing pattern of the remaining entities is persistent, thereby demonstrating their belonging to a 
The Correlation between Romanian Financing Pattern of Firms and Fixed Capital Formation in the Real Sector

financing pattern based chiefly on either debt or equity most of the time before the crisis erupted. It is worth mentioning that out of the firms in operation between 2004 and 2008 the overwhelming majority (80\% i.e. 412,285 units out of 516,354 analysed companies) fell into the group of companies whose funding was provided mainly by creditors, as they reported an above-par debt-to-equity ratio or negative equity over at least 3 years of the reviewed period.

Overly-indebted companies had, on average, a particularly high indebtedness of $558 \%$ (debt was more than 5 times higher than own financing sources), compared to the firms in the second groups whose leverage (calculated as a ratio of debt to equity) was below par, at only $42 \%$.Overly-indebted firms were characterised also by a lower degree of financial autonomy in the near run, with circulating assets covering only $85 \%$ of short-term debt, compared to the entities with a below-par level of indebtedness, whose current ratio ${ }^{6}$ was almost double at $163 \%$. Moreover, return on assets $(\mathrm{ROA})^{7}$ in the case of overly-indebted companies was substantially lower than for the firms with a more prudent financial standing (5.1\% versus 9.8\%).Conversely, greater indebtedness appears to have had a positive effect on the investment rate ${ }^{8}$, posting slightly higher levels for heavilyindebted firms ( $15.3 \%$ versus $13.6 \%$ for companies with a below-par leverage). They also displayed a more cyclical economic activity, with an average annual growth rate of gross value added (GVA) at $28.1 \%$, exceeding the economy-wide average of $22.3 \%$ and overtaking by far the firms with below-par leverage, which reported a slower pace of increase, on average, at $15.2 \%$.

Then we looked at developments in key financial indicators of the two groups of companies after the crisis broke out, i.e. between 2009 and 2017, narrowing the sample to firms that continued to operate for at least 3 years during that period in order to render the analysis of the path of economic indicators more robust in the recent period. It is, thus, avoided the volatility in indicators caused by the companies that made early market exit during the crisis and had, obviously, very fragile financial statements. It notes that among the heavily-indebted firms when the crisis broke out, only $67.5 \%$ continued to operate during at least 3 years in the post-crisis period, which is lower than in the case of companies with below-par leverage, which stayed in the market for more than 3 years at a rate of $72.8 \%$. Specifically, the early market exit rate of overly-indebted firms is a first sign of their greater vulnerability to adverse economic events, owing to weak capitalisation and high reliance on creditors' funding sources. In fact, from 2009 to 2017, the gap between key economic indicators of overly-indebted firms and those of firms with a more prudent financial standing at the outbreak of the crisis

\footnotetext{
${ }^{6}$ Circulating assets/short-term debt

${ }^{7}$ We did not analyse the return on equity, as this is distorted by the weak capital base of overly- indebted firms.

${ }^{8}$ Measured as a share of the annual change in fixed assets, including depreciation costs, in firms' total assets.
} 
Florin Georgescu, Gheorghe Gherghina, Ana-Maria Cazacu

persisted in terms of both indebtedness (530\% versus $49 \%)$, short-term financial autonomy (current ratio of $84 \%$ versus 140\%) and profitability (ROA of $2.9 \%$ against 5.8\%), Table 1.It should be underscored that the adjustment of the postcrisis investment rate for overly-indebted firms was more pronounced between 2009 and 2017, as this rate dropped 10 percentage points over the average for 2004-2008 (from $15.3 \%$ to $5.3 \%$ ), while the decline was lower at 7.3 percentage points (from $13.6 \%$ to $6.3 \%$ ) for the firms with a below-par debt-to-equity ratio.

Table 1. Firms' financial standing by level of indebtedness in 2009-2017

\begin{tabular}{|c|c|c|}
\hline Indicator & $\begin{array}{c}\text { Overly-indebted firms in } \\
\text { the pre-crisis period }\end{array}$ & $\begin{array}{c}\text { Firms with below-par } \\
\text { debt-to-equity ratio in the pre-crisis period }\end{array}$ \\
\hline Debt-to-equity ratio & $530 \%$ & $49 \%$ \\
\hline Current ratio & $84 \%$ & $140 \%$ \\
\hline ROA & $2.90 \%$ & $5.80 \%$ \\
\hline Investment rate & $5.30 \%$ & $6.30 \%$ \\
\hline $\begin{array}{c}\text { GVA annual growth } \\
\text { rate }\end{array}$ & $1 \%$ & $0.7 \%$ \\
\hline
\end{tabular}

Note: average values in the period 2009-2017 for the companies that submitted financial statements to the MPF for at least 3 years in this period.

Source: $M P F$, authors' calculations

Thus, compared to the pre-crisis period, when overly-indebted firms carried out relatively brisker investment activity than those with a below-par debt-toequity ratio, the former's investment rate in the recent period was lower than that of firms with a more adequate financing pattern. The difference in the distribution of investment rate for the two groups was confirmed by the Kolmogorov-Smirnov test. If $\mathrm{F}$ and $\mathrm{G}$ are the cumulative distribution functions of the investment rate for companies with below-par debt-to-equity ratio and for overly-indebted firms, respectively, the two sided Kolmogorov-Smirnov test indicates whether the two distributions are drawn from the same distribution, while the one sided test establishes the first order stochastic dominance of $F$ relative to $\mathrm{G}$, namely:

(1) Two sided test:

$$
H_{0}: F(x)-G(x)=0 \text { for all } \mathrm{x} \in \mathrm{R}
$$

(2) One-sided test:

$H_{0}: F(x)-G(x) \leq 0$ for all $\mathrm{x} \in \mathrm{R}$

In our case, the null hypothesis $\left(\mathrm{H}_{0}\right)$ for the two sided test is rejectedat $1 \%$ significance threshold, showing that the two distributions are not drawn from the same underlying continuous distribution, while the one-sided test confirms that the distribution of the investment rate for firms with below-par debt-to-equity ratio dominates the one of overly-indebted companies $\left(\mathrm{H}_{0}\right.$ cannot be rejected).

In fact, during the years that followed the outbreak of the economic crisis, investment rate of overly-indebted firms declined sharply, to a paltry $56 \%$ of the 2008 level in 2009 and merely $23 \%$ in 2010 (Chart 1). Investment recovery for this group of companies proved to be more cumbersome, so that in 2012 investment 
The Correlation between Romanian Financing Pattern of Firms and Fixed Capital Formation in the Real Sector

rate was still lagging much behind the 2008 level (32\%). Conversely, firms with a below-par debt-to-equity ratio when the crisis hit saw a lower adjustment, so that in 2009 investment rate fell to $70 \%$ of the 2008 level and from 2010 to 2012 investment rate for this group of companies ranged between $50 \%$ and $61 \%$ of the 2008 figure. The result is in line with that mentioned by Özcanet al. (2018), showing that EU firms with a higher level of indebtedness and a larger share of short-term debt when the crisis broke out squeezed their investment more substantially in the post-crisis years. These developments show that originally, at the time of granting the loans, debts can help, to some extent, to launch or expand investment projects, the debt overhang becomes over time - particularly amid negative economic shocks - a factor depressing capital formation. This is also because the elevated indebtedness erodes business partners' confidence and contains access to additional funding, or drives its cost higher, thereby making heavily-indebted companies more vulnerable to fluctuations in economic activity.

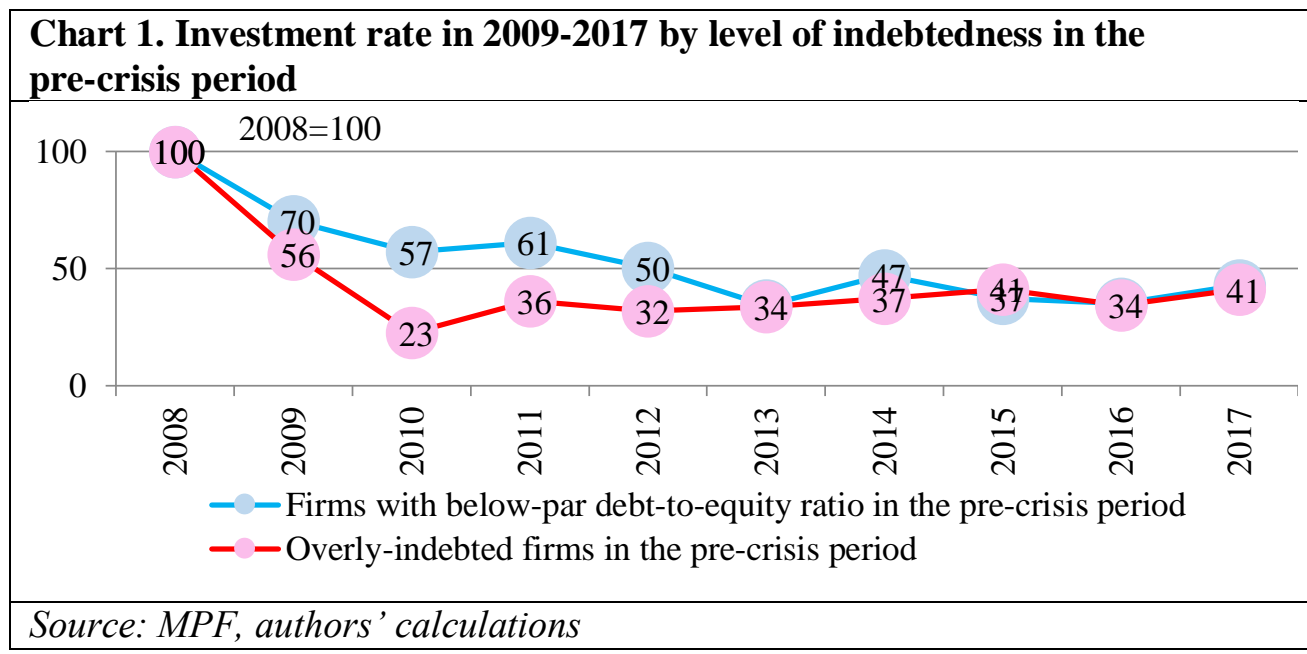

Starting 2013, Romania has experienced a propensity for relatively low investment in the case of the two groups of firms. In 2017, investment rate accounted for little over $40 \%$ of the 2008 level, for both overly-indebted companies at the outbreak of the crisis $(41 \%)$ and those with a more prudent financial standing (53\%). The corporate sector's weak appetite for investment stifles Romania's economic competitiveness, especially as the public sector also faces constraints leading to tepid investment. As the share of compensation of employees in GDP stands at one of the lowest readings in the region (40\% of employees in Romania earn the economy-wide minimum wage), the government has latterly adopted an incentive-based policy addressing labour (by heavily employing the lever of minimum wage and sharply boosting pays in some areas of the public sector). This prompted a relative slowdown in investment, being one of 
the effects of the fact that, at present, the fiscal area in Romania deals with an impossible trinity: (1) raising citizens' purchasing power, along with developing physical and human infrastructure; (2)keeping the fiscal deficit below 3\% of GDP, while narrowing the structural deficit; and (3) failing to use, given the faulty distribution of newly-created value in the economy, fiscal policy as a redistribution lever between production factors (capital and labour) and, within them, based on criteria that are economically stimulative and socially correct. As in any of the similar situations, policy makers are bound to sacrifice one of the three objectives and make a decision tailored to the state of the economy and the intensity of social pressures.

Behind the slow increase in fixed capital also stood the fact that EU funds' contribution to fixed capital formation does not post an adequate level relative to Romania's development needs. As yet, under the EU's multiannual financial framework 2007-2013, only a small percentage of capital transfers from EU funds was detected in the private sector $(26.2 \%$, or EUR 5.6 billion) and, within this sector, mostly areas with a low productive potential were targeted, and only $26.8 \%$ of capital financing in the private sector (7\% of total capital transfers, or EUR 1.5 billion) were channelled to industry, construction and transport (of which much was used by foreign-owned firms), helping boost the volume and quality of fixed capital in the economy via the multiplication effect. Consequently, one may conclude that EU funds absorption played a marginal role in the quantitative and qualitative formation of fixed capital in the domestic real economy.

Turning to developments in GVA in the post-crisis period it notes that, similarly to the investment rate, the adjustment was stronger in the case of overlyindebted firms, so that from 2009 to 2017, average annual growth of GVA neared that of firms with a more prudent financial structure (compared to the pre-crisis years when the indicator for overly-indebted firms had risen much quicker than for the companies with below-par leverage). The differential between GVA growth rates for the two groups of companies narrowed from 12.9 percentage points ( $28.1 \%$ versus $15.2 \%$, the average annual growth of GVA in the period 2004-2008 for heavily-indebted firms, i.e. entities with below-par leverage) to 0.3 percentage points (1\% against $0.7 \%$ in 2009-2017). This is in line with the conclusions of other papers showing that elevated indebtedness may lead, over a certain timeframe, to a more aggressive, yet riskier, production behaviour, with firms being vulnerable to significant corrections when shifting from boom to bust.

Drawing on the papers showing a negative relationship between leverage and productivity (Nucci et al., 2005), we also analysed the developments in labour productivity ${ }^{9}$ across the corporate sector, based on the financial structure when the crisis broke out. Specifically, in the period 2004-2008, the firms with higher leverage were found to have recorded significantly weaker productivity levels than those with a below-par debt-to-equity ratio. At all moments of the distribution of this indicator, productivity of the former group of companies was about $40 \%$ lower

${ }^{9}$ The ratio of GVA to the number of employees. 
The Correlation between Romanian Financing Pattern of Firms and Fixed Capital Formation in the Real Sector

than that of firms with below-par leverage (e.g., the median of labour productivity of heavily-indebted firms amounted to lei 15,500 per employee, compared to lei 26,300 per employee in the case of firms with a more prudent financial standing). Although this gap narrowed slightly in the post-crisis period, worth mentioning is that the group of firms with low financial autonomy when the crisis broke out continues to post poorer productivity, having a negative impact on the efficient resource allocation and, thus, on the sustainable growth of the economy.Therefore, high indebtedness makes firms vulnerable to adverse economic events, as evidenced by the steeper contraction in investment during the post-crisis period. Furthermore, low productivity of these firms and their more pro-cyclical economic activity have negative effects on the efficiency of the business environment and the accumulation rate of fixed capital, thereby affecting Romania's competitiveness and growth prospects.

\section{Hidden economy and its impact on capital formation}

Aside from the above-mentioned aspects, underscoring the low stock of fixed capital in the economy and the poor quality of investment amid elevated indebtedness of many companies in Romania's economy, another factor having a negative effect on capital accumulation and, implicitly, effective and potential GDP refers to the hidden economy ${ }^{10}$. This informal component of the economy is defined as encompassing all the activities concealed by economic agents from the authorities for tax-related reasons (avoidance of paying taxes and social security contributions), regulatory reasons (circumvention of the regulatory framework) and institutional reasons (flawed law enforcement, poor quality of government institutions and related corruption acts).Hidden economy also implies a large number of firms, which are typically small, inefficient, bearing in mind that they are decapitalised and have limited access to bank financing and use various illegal channels to acquire the necessary resources or to sell their products and services. Informal firms in the sector employ additional resources to cover the traces of their illegal activities (La Porta and Shleifer, 2014), causing little inclination to engage in investment activities. Loayza (2018) shows that companies operating in the informal sector have a negative influence on the economy-wide resource allocation, with significantly lower productivity than the rest of firms, and their

\footnotetext{
10 Hidden economy refers to all productive activities that cannot be captured in the underlying data sources used to aggregate information for the national accounts. It covers activities that are deliberately circumvented from reporting to the public authorities, in both formal and informal sectors. According to the European System of Accounts, the underground economy in the formal sector refers to the entire production not recorded by administration and taxation bodies, due to their non-reporting by economic agents, with the aim of dodging tax payments, including the use of black labour. Adding to these are illegal activities, such as drug trafficking, alcohol and tobacco smuggling, prostitution, etc. Among the most frequently used determiners for the 'hidden' economy are: informal, underground, grey, shadow, unobserved, black, unofficial, non-taxed (Pisică, 2011).
} 
efficiency indicators fare all the more poor as the size of the hidden economy rises. The informal economy also has an indirect negative effect on total investment, considering that gross value added in this sector is not taxed, which reduces the government's resources that may be allocated to areas that are badly in need of additional funds (healthcare, education, physical infrastructure, etc.). Actually, Romania's budget revenues, particularly those of a fiscal nature, are at worryingly low levels $(25.7 \%$ of GDP in 2017, 14.3 percentage points below the EU-wide average of 40\%). Moreover, it should be pointed out that, between 2004 and 2017, the share of hidden economy in GDP widened from $14 \%$ to $21 \%$, according to European methodology-compliant estimates by Romanian statisticians. At the same time, GDP increased by a real 55\% and the hidden economy expanded by $127 \%$, pointing to an advance of $43 \%$ in taxable GDP (GDP net of the hidden economy), 12 percentage points lower than GDP growth recorded by official statistics. The most toxic segment of the hidden economy relates to tax evasion, which covers informal, or 'black', labour as well. In fact, in Romania, underreported value added because of informal labour ${ }^{11}$ in the enterprises registered in the formal economy makes up the largest part of hidden economy (53.5\% of total in 2017, a level similar to 2004). When hidden economy is dominated by black labour, the informal economy can be mostly considered a subsistence economy. The large weight of hidden economy in Romania entails serious distortions in applying the allocation and redistribution functions of the general consolidated budget as, actually, only $79 \%$ of effective GDP is taxable in order to supply public goods and services to citizens. At the same time, the countries with a low share of hidden economy in GDP - generally the developed Western countries - display a high level of taxable GDP, paving the way for the fulfilment of citizens' needs for public goods and services at much higher quantitative and qualitative standards, thereby helping boost potential and effective GDP.

Besides the hidden economy, there is another segment failing to generate tax revenues, i.e. household production for own use ${ }^{12}$. By examining the period $2010^{13}-2017$, we found that the value of this indicator (non-traded GVA) stood 6\% higher in real terms, with its share of GDP contracting, however, from $12 \%$ to $10 \%$. In fact, since 2010, the share of household production for own use as a percentage of GDP, together with hidden economy, has followed a downward path (from $37 \%$ to $31 \%$ in 2017). The combined level of both components remains, however, at elevated levels. Other authors (Medina and Schneider, 2018) also show that informal economy has one of the largest shares in Romania among EU

\footnotetext{
${ }^{11}$ Black labour is, in principle, associated with labour tax evasion. The other part of hidden economy in the formal sector refers to the avoidance of paying VAT on (undeclared) informal turnover.

${ }^{12}$ Household production for own use includes gross value added related to: imputed rent, home industry, self-consumption and self-build housing.

${ }^{13}$ Period conditioned by the availability of data on household production for own use.
} 
The Correlation between Romanian Financing Pattern of Firms and Fixed Capital Formation in the Real Sector

Member States. Specifically, the study estimates that, in 2017, the "hidden" economy in Romania accounted for $26.3 \%$ of GDP, well above the EU 28 average of $17.3 \%$ of GDP. The dismal performance places Romania at the bottom of the European ranking, before Croatia and Bulgaria on $26.5 \%$ and $29.6 \%$ respectively. Worth mentioning are the countries posting levels below the EU average in terms of the informal economy, both advanced economies such as Austria (7.1\% of GDP), Luxembourg (8.2\% of GDP), the Netherlands (8.4\% of GDP), the United Kingdom (9\% of GDP), Ireland and Germany (10.4\% of GDP), but also former socialist countries in the region: Slovakia (13\% of GDP), Czechia (14.1\% of GDP), etc.

\section{Final remarks}

This study points out that firms' financing structure has direct effects on formation and accumulation of fixed capital, which, in turn, is the key driver of effective and potential economic growth. These findings were confirmed by dedicated papers published internationally. Romania's endowment with fixed capital is weaker than in most developed countries in Europe, in terms of both GDP and the number of employees, given that the local corporate sector is characterised by a small share of stockholders' equity in total funding resources. Against this backdrop, the ratio of equity to fixed assets of firms in Romania is significantly lower (64\% in 2017) than in other countries where shareholders' equity of companies exceeds fixed assets. The lack of enough funding sources in relation to the fixed capital stock prompts a low level of investment in Romania and, in addition, when companies have the possibility to invest, the money is only partly channelled into complex, modern/automated production means, being used, in general, to replace and moderately increase the present fixed assets (which has an extensive rather than an intensive nature).Hence, domestic firms' high reliance on creditors and, implicitly, limited autonomy in fixed capital financing raises concerns over the stability, quality and complexity of the productive capital stock in the corporate sector. In fact, the developments in Romania in the aftermath of the crisis show that overly-indebted firms have a financial standing vulnerable to adverse economic events, as evidenced by their more pronounced adjustment in key performance indicators relative to the companies with a more prudent financial structure. Specifically, the capability to generate value added, the level of productivity and investment of overly-indebted firms have dropped substantially since 2009 compared to the period of economic boom.

Those developments point to the negative impact that undercapitalised companies have on the efficiency of the business environment and the accumulation rate of fixed capital, thereby affecting Romania's competitiveness and growth prospects. The current state demonstrates the need to implement major legislative and institutional corrections aimed at removing the abnormal behaviour relative to the requirements of a genuine market economy. It is therefore necessary that the government should focus on the implementation of reforms to ensure 
quantitative, qualitative and structural improvements in production factors in the real sector, especially via massive recapitalisation of undercapitalised firms, and to make firms comply with the payment terms to their creditors, pursuant to European practice, transposed into Romanian legislation. In this vein, it should be pointed out the relatively recent proposal by the European Commission (2016) that stimulates fixed capital financing from own sources, i.e. providing tax deductions from the calculation base of profit tax for the firms that opt for covering investment expenses by raising shareholders' equity (via reinvestment of earnings or share issues). At the same time, the legislative proposal aiming to build a consolidated common fiscal basis of EU-wide firms also includes incentives for innovation activities. The companies funding R\&D activities will be able to deduct from the tax base the total cost of such investment, to which adds an additional percentage of outlays, depending on the invested amount.

As for tackling the issue of the capital shortfall (in amount of EUR 33 billion in 2017), it should be pointed out that a large part (EUR 9.9 billion, or 30\% of total) is available to undercapitalised companies in the form of loans from their owners. Aside from the shareholders' contribution, another segment of deficitfinancing sources is the individual financial wealth, which grew markedly in the reported period, since many individuals with undercapitalised businesses may own substantial financial assets (Georgescu, 2018). An area with considerable money resources envisages cash in circulation, as part of it can be used to bridge the deficit by undercapitalised firms' shareholders. In our opinion, the law should clearly stipulate conditions to ensure how serious entrepreneurs are when doing business (an adequate level of initial share capital that must be preserved over the firm's lifetime), as well as conditions for early market exit by decapitalised firms whose owners no longer have the financial capacity or willingness to make fresh capital contributions. These measures are necessary as entrepreneurs in Romania enjoy a very high degree of freedom, as they are not bound to assume responsibility in keeping with the scale and the risk of the adopted economic decisions, which cannot lead but to an entirely atypical market economy, i.e. hybrid capitalism. The improvements needed to be made to Law 31/1990 on trading companies and bankruptcy proceedings (for the protection of creditors in relation to debtors) will help connect Romania's economic legislation to the practices of advanced economies in Europe and lay the groundwork for capital to become the genuine engine of sustainable economic growth in our country.

The elevated non-taxed economic activity, depressing both gross fixed capital formation and the employees' working conditions (characterised, in general, by a poor working environment, limited access to social protection and low wages), also demonstrates the need for substantial improvements in legislation and in the instruments for implementing fiscal policy in Romania. In this vein, fiscal consolidation is, in our opinion, the top priority within this package of reforms considering the very low share of tax revenues in GDP (25.7\% in 2017 compared to the EU-wide average of $40 \%$. Behind the poor fiscal performance stood both weak efficiency of revenue collection and low tax rates. Calculations show that an 
The Correlation between Romanian Financing Pattern of Firms and Fixed Capital Formation in the Real Sector

improvement in revenue collection up to Bulgaria's performance would add around 4 percentage points (from $26 \%$ to $30 \%$ of GDP) and an effectiveness of collection similar to that in developed countries would translate into a gain of 5 percentage points (Georgescu, 2018). However, in order to secure a solid basis of fiscal revenues for the provision of public goods and services, a substantial revision of the taxation system is called for, without affecting the corporate sector, focusing on progressive taxation of individuals' personal income and property. This measure is an objective requirement given the major structural changes in the distribution of households' income and wealth over the last nearly 30 years.

Against this background, it is worth recalling the statements made by Timmer ${ }^{14}$ (2018): "starting from the growing inequalities in Europe, prompting general anxiety and a sense of mistrust of people in the future, and in Eastern Europe mass migration of youth to the West, the tax system needs to be changed by moving from a flat to a progressive taxation regime, i.e. those earning more should pay a higher percentage of taxes". Along with optimising and modernising tax legislation, the authorities must take measures to slash squandering and fraud in spending public money (illegal "drains" of such funds are now part of untaxed personal income), since Romania underperforms in terms of "efficiency of public expenditures", ranking 115th out of 137 countries (World Economic Forum, 2018). Moreover, according to the IMF Fiscal Monitor (October 2018), another source for additional fiscal revenues is the effective management of government's financial and non-financial assets, which could generate additional revenues close to $3 \%$ of GDP, similarly to the corporate tax receipts in advanced economies.

Romania's experience with social and economic changes in the postcommunist period, including the developments described above, shows that at present, in our opinion, the focus must be on ensuring discipline in designing and implementing economic policies. Against this background, besides the sustainable fulfilment of nominal convergence criteria, real convergence can be achieved as well. The multitude, complexity and difficulty of reforms that need to be implemented in the real sector (especially the massive capitalisation of firms and enforcement of firm payment discipline) and in terms of fiscal consolidation lead to the conclusion that such major changes cannot be achieved, given the young democracy and the fledgling market economy in Romania, otherwise than in a solid partnership with international institutions recognised for their professionalism and prestige such as the European Commission and the European Central Bank, by assuming a substantive, realistic, yet ambitious action plan with firm deadlines for entering the Exchange Rate Mechanism II (ERM II) and subsequently the euro area. In supporting the option for speedy entry into ERM II and subsequently the euro area, we are aware that Romania, once in the euro zone "waiting room", can no longer use currency depreciation as a competitiveness-enhancing tool. An increase in competitiveness shall only be ensured, under the new circumstances,

\footnotetext{
${ }^{14}$ Chief economist for Europe and Central Asia at the World Bank.
} 
Florin Georgescu, Gheorghe Gherghina, Ana-Maria Cazacu

via in-depth structural reforms aimed at boosting potential GDP. In fact, the ECB views the ERM II as a useful regime, which is designed as a training/testing room, meant chiefly to discipline macroeconomic policies and to foster structural transformations. We consider that the implementation of the key structural reforms, i.e. capitalisation and payment discipline in the corporate sector, as well as fiscal consolidation, especially through the introduction of progressive tax on personal income and property, besides determination and professionalism, implies to ensure a proper mix with an adequate dosage of macroeconomic (fiscal, monetary, income and macroprudential) policies. In our opinion, decision-makers' effective action at micro- and macroeconomic levels must rely, as an anchor and a lever for disciplinary purposes, on the action plan for euro adoption assumed as a nationwide project by government authorities and the civil society alike. Romania's option for a speedier entry into ERM II and euro adoption represents the integration into a virtuous economic and social chain comprising: discipline in implementing macroeconomic policies and structural reforms (particularly corporate sector recapitalisation and fiscal consolidation) - increase in confidence among citizens and in their confidence in state institutions -national reconciliation - sustainable economic recovery - fast-track real convergence - lasting wealth for every citizen.

\section{REFERENCES}

[1] Altăr, M., Necula, N., Bobeică, G. (2010), Estimating Potential GDP for the Romanian Economy. An Eclectic Approach, RJEF 3/2010;

[2] Brander, J., Lewis, T. (1986), Oligopoly and Financial Structure: The Limited Liability Effect; The American Economic Review, Vol. 76, No 5, pp. 956-970;

[3] Diewert, W. E. (2014), The Treatment of Financial Transactions in the SNA: A User Cost Approach, Eurostat;

[4] Duval, R., Hong, G.H., Timmer, Y. (2017), Financial Frictions and the Great Productivity Slowdown; IMF Working Paper No. 129;

[5] European Commission (2016), Proposal for a COUNCIL DIRECTIVE on a Common Corporate Tax Base 2016/0337;

[6] European Investment Bank (2018), EIB Investment Survey;

[7] Gebauer, S., Setzer, R., Westphal, A. (2017), Corporate Debt and Investment: A Firm Level Analysis for Stressed Euro Area Countries; ECP WP 2101;

[8] Georgescu, F. (2018), Capitalul în România post comunistă; Romanian Academy Publishing House, Bucharest;

[9] Guda, I. (2018), Cine (mai) face investiții în România?, 23 September; 
The Correlation between Romanian Financing Pattern of Firms and Fixed Capital Formation in the Real Sector

[10] International Monetary Fund (2018), IMF Fiscal Monitor, October

[11] Kalemli-Özcan, S., Laeven, L., Moreno, D. (2018), Debt Overhang, Rollover Risk, and Corporate Investment; NBER Working Paper 24555;

[12] Keuning, S. (1999), The Role of Financial Capital in Production; The review of income and wealth, Vol. 45, Issue 4, pp. 419-434;

[13] Keuning, S. (2009), What kind of GDP for 2020?, 16 September, Brussels;

[14] La Porta, R., Shleifer, A. (2014), Informality and Development; The Journal of Economic Perspectives 28 (3): 109-26;

[15] Leach, J.C., Moyen, N., Yang, J. (2004), On the Strategic Use of Debt and Capacity in Imperfectly Competitive Product Markets;

[16] Loayza, N. (2018), Informality: Why Is It So Widespread and How Can It Be Reduced?, Research \& Policy Briefs No. 20, December;

[17] Medina, L., Schneider, F. (2018), Shadow Economies around the World: What Did We Learn over the Last 20 Years?, IMF Working Paper No. 17;

[18] Modigliani, F., Miller, M. (1958), The Cost of Capital, Corporation Finance and Theory of Investment; American Economic Review, Vol. 48: 261-297;

[19] National Bank of Romania (2019), Inflation Report, February;

[20] Nucci, F., Pozzolo, A., Schivardi, F. (2005), Is Firm's Productivity Related to Its Financial Structure? Evidence from Microeconomic Data; Rivista di Politica Economica, SIPI Spa, Vol. 95(1), pp. 269-290, January;

[21] Pisică, S. (2011), Informal Sector on Labour Market - Theoretical Considerations; Romanian Statistical Review No. 5/2011;

[22] Timmer, H. (2018), Banca Mondială, după 20 de ani de reforme sub ghidajul său; Ziarul financiar newspaper, 22 October;

[23] WEF (2018), The Global Competitiveness Report 2018-2019, Geneva. 